\title{
INFOTAINMENT I DEZINFORMACJA W MEDIACH ROSYJSKOJĘZYCZNYCH W PAŃSTWACH BAŁTYCKICH
}

\author{
Aleksandra Kuczyńska-Zonik \\ Instytut Europy Środkowej w Lublinie \\ ORCID ID: https://orcid.org/0000-0002-5672-9613 \\ e-mail: kuczynska.zonik@ies.lublin.pl
}

\begin{abstract}
Streszczenie: Celem niniejszego artykułu jest analiza dyskursu informacyjnego w państwach bałtyckich ze szczególnym uwzględnieniem mediów rosyjskojęzycznych będących pod wpływem oddziaływania ze strony Rosji. Przeprowadzone badania mają dać odpowiedź na pytanie o efektywność przekazu informacyjnego obarczonego manipulacją i dezinformacją. Punktem wyjścia jest stwierdzenie, że obecny kryzys informacyjny w państwach bałtyckich jest wynikiem kształtowania nowego typu infotainment, który efektywnie absorbuje uwagę odbiorców rosyjskojęzycznych w państwach bałtyckich oraz wzmacnia i sakralizuje narracje dotyczące pozycji i interesów Rosji w środowisku międzynarodowym.
\end{abstract}

Słowa kluczowe: infotainment, dezinformacja, państwa bałtyckie, Rosja

\section{WPROWADZENIE}

Zdominowanie sfery mediów przez ideologie zaciera charakter informacji jako dobra publicznego [Goban-Klas 2011] na korzyść rozrywki. Dla państw bałtyckich szczególne wyzwania w sferze informacyjnej wiążą się z oddziaływaniem Rosji, dla której zasadniczymi metodami są wysoka atrakcyjność (infotainment) oraz manipulacja informacjami. Zaczerpnięty od Neila Postmana (1985) neologizm będący połączeniem terminów information (informacja) i entertainment (rozrywka) oznaczający „oparte na informacji treści medialne lub programowanie, zawierające dodatkowo treści rozrywkowe w celu zwiększenia popularności wśród odbiorców i konsumentów" [Demers 2005; Langman 2015] zyskał na znaczeniu na przełomie lat 80. i 90. ostatniego stulecia. Obecnie termin ,informacja rozrywkowa” odnosi się do mieszania poważnych, niekiedy dramatycznych treści z lekką, rozrywkową formą [Nowak 2009], którego konsekwencją jest obniżenie jakości faktów (ma- 
nipulacja, deformacja, selekcja) i dewaluacja postaci (ośmieszanie, przekraczanie granic prywatności) [Wolny-Zmorzyński, Kaliszewski, Furman 2006].

Atutem mediów rosyjskojęzycznych jest odpowiedni dobór tematów i sposobów ich prezentowania, które zapewniają rozrywkę i przyjemny sposób spędzania wolnego czasu. Efektywność wpływu informacyjnego wiąże się z obecnością mniejszości rosyjskojęzycznej, w szczególności na Łotwie i w Estonii, gdzie mniejszości stanowią odpowiednio 32\% i 28\% mieszkańców. Na Łotwie zamieszkuje ona głównie region Łatgalii (60\% populacji) i miasto Dyneburg (54\%). W Rydze etniczni Rosjanie stanowią niemal 40\% mieszkańców (osoby rosyjskojęzyczne to ponad połowa mieszkańców). W Estonii mniejszości rosyjskojęzyczne koncentrują się w północno-wschodniej części państwa i w stolicy (etniczni Rosjanie to 37\% mieszkańców Tallina). W regionie Ida-Virumaa 84\% populacji stanowią osoby rosyjskojęzyczne, podczas gdy $47 \%$ posiada rosyjskie obywatelstwo lub w ogóle nie posiada obywatelstwa (tzw. obywatelstwo nieokreślone). Na Litwie osoby pochodzenia rosyjskiego stanowią ok. 5\% mieszkańców.

Od lat 90. XX wieku państwa bałtyckie prowadziły polityki integracyjne wobec własnych mniejszości narodowych, jednak dotychczasowe badania socjologiczne wskazują na relatywnie niski stopień integracji i potrzebę zachowania przez nie własnej kultury [Ozolina 2016]. Podobnego zdania byli Nils Muiznieks (2010) oraz Ieva Birka (2016), którzy badali spójność społeczną oraz podatność osób rosyjskojęzycznych na wyzwania integracyjne. Kwestia ta jest szczególnie istotna w warunkach nasilonego wpływu (soft power) ze strony Rosji [Laruelle 2015; Pomerantsev 2015], a zwłaszcza w kontekście mediów, które kształtuje proces społeczno-kulturowy [Novikova 2014].

W kontekście problemów integracyjnych i zagrożeń społecznych w państwach bałtyckich media rosyjskojęzyczne pełnią istotną rolę. Media rosyjskojęzyczne informują o zjawiskach interesujących ich odbiorców (osób rosyjskojęzycznych), ważnych z ich punktu widzenia: o nich samych i ich problemach, stosunkach z Rosją, bezpieczeństwie, rosyjskich wartościach i kulturze. Poświęcają więcej uwagi szkolnictwu w językach mniejszości, a w ostatnim czasie wojnie na Ukrainie. Informacje lokalne są ważniejsze niż te o tematyce międzynarodowej. Media kreują pozytywny wizerunek osób rosyjskojęzycznych i Rosji, obarczając winą rządy państw bałtyckich, USA i NATO za obecną sytuację polityczną, społeczną i gospodarczą państwa oraz status mniejszości. Wzbudzają poczucie krzywdy, niesprawiedliwości i budują sowieckie resentymenty. I tak, analityczny portal RuBaltic.ru, działający od 2013 r. uzasadnia, że u podstaw jego działalności leżą „procesy polityczne rozwijające się obecnie na Litwie, Łotwie i w Estonii - wzrost autorytarnych tendencji, pogorszenie sytuacji gospodarczej, degradacja społeczna”. Dodaje, że: „Ten konfliktowy proces tworzy destrukcyjne tło dla rozwoju państw postradzieckich, pogłębienia integracji euroazjatyckiej i normalizacji dialogu między Rosją a Unią Europejską".

Rosyjskojęzyczne środowisko informacyjne w państwach bałtyckich jest odzwierciedleniem procesów zachodzących w przestrzeni medialnej w Rosji, 
widocznych zwłaszcza po wyborach parlamentarnych (2011) i prezydenckich (2012), a następnie aneksji Krymu i wojnie na Ukrainie (2014), kiedy w mediach rosyjskich zaczęły się pojawiać szczegółowe informacje dotyczące działań władz legitymizowanych narodowymi interesami Rosji, idealizujące obraz Rosji oraz agresywne treści wobec jej wrogów [Novikova 2014]. Prezentują informacje, które osoby rosyjskojęzyczne chcą usłyszeć, potwierdzają ich punkt widzenia i umacniają ich w przekonaniach, najczęściej zniekształcając fakty i manipulując przekazem. Określone zasady działań propagandowych zapewniają skuteczność i efektywność strategii informacyjnej Rosji [Darczewska 2014].

Celem niniejszej pracy jest analiza dyskursu informacyjnego w państwach bałtyckich ze szczególnym uwzględnieniem mediów rosyjskojęzycznych będących pod wpływem oddziaływania ze strony Rosji. Celem badań jest odpowiedź na pytanie o efektywność przekazu informacyjnego obarczonego manipulacją i dezinformacją. Punktem wyjścia jest stwierdzenie, że obecny kryzys informacyjny w państwach bałtyckich jest wynikiem kształtowania nowego typu infotainment, który efektywnie absorbuje uwagę odbiorców rosyjskojęzycznych w państwach bałtyckich oraz wzmacnia i sakralizuje narracje dotyczące pozycji i interesów Rosji w środowisku międzynarodowym. Konsekwencją tego rodzaju komunikacji jest obniżenie jakości przekazu wspomagane dodatkowo przez manipulację faktami i fałszowanie informacji (propaganda). Wykorzystane w pracy materiały źródłowe: prasowe („Segodnya”, „Express Nedelya”), telewizyjne (PBK) i internetowe (Vesti.lv, Press.lv, Baltnews, Sputnik), monografie i inne opracowania naukowe posłużyły odpowiedzi na pytania dotyczące złożonych relacji między atrakcyjnością formy i propagandową treścią przekazu informacyjnego stanowiącego jeden z istotnych elementów wpływu Rosji w Europie Środkowo-Wschodniej.

\section{SPECYFIKA MEDIÓW ROSYJSKOJĘZYCZNYCH W PAŃSTWACH BAŁTYCKICH}

Programy i kanały w języku rosyjskim są nadawane w mediach państwowych oraz niezależnych (m.in. Delfi, Postimees, Re:Baltica). Przedmiotem niniejszego opracowanie są media należące do rosyjskich grup medialnych, które transmitują bezpośrednio rosyjską treść na Litwie, Łotwie i w Estonii, lub są to media w języku rosyjskim, których zawartość jest wzorowana na treści mediów rosyjskich. Zazwyczaj są finansowane ze źródeł rosyjskich i od nich zależne, co wpływa na ich jakość i sposób prezentacji wydarzeń politycznych i społecznych. Łotewski holding medialny Baltijas Mediju Alianse transmituje rosyjskie kanały telewizyjne na Litwie, Łotwie i w Estonii, w tym Pervyy Baltiyskiy kanal, PBK (Первый Балтийский канал) oraz kanały telewizyjne na podstawie zawartości medialnej rosyjskiego kanału NTV-Mir (HTB-Mup), wydaje rosyjskojęzyczną prasę MK-Latviya (МК-Латвия) і MK-Estoniya (МК-Эстония) oraz prowadzi 
strony internetowe w tym języku. Na Łotwie i w Estonii PBK jest jednym z najpopularniejszych, oglądany przez $8,7 \%$ i 5,7\% odbiorców w tych państwach. Z kolei NTV Mir plasuje się na piątym miejscu pod względem liczby odbiorców na Litwie, Łotwie i w Estonii (odpowiednio 4,9\%; 7,6\% i 5,3\% mieszkańców) [Krūtaine, Loit, Staselis, Puriņa 2017].

Łotwa jest jedynym państwem bałtyckim, w którym trzy spośród pięciu najbardziej popularnych tytułów prasowych wydawanych jest w języku rosyjskim. Są to „MK-Latviya” (МК-Латвия, w 2015 r. jej nakład wynosił 198 tys. egzemplarzy), „Segodnya” (Сегодня) i „Latvijskie Vesti” (Латвийские Вести). Dominuje tu retoryka etniczna. Media poświęcają wiele uwagi sprawom rosyjskojęzycznym, problemom socjalnym, podkreślają wartości i tradycję rosyjską, odnoszą się do rosyjskich korzeni w państwowości łotewskiej, bagatelizując politykę państwa i całego społeczeństwa. Prasa rosyjsko- i łotewskojęzyczna są całkowicie od siebie niezależne. Dlatego ocena wydarzeń i zjawisk w państwie w tych dwóch mediach zdecydowanie się różni. To znacznie ułatwia Rosji działania propagandowe i pozostawia mniejszości rosyjskojęzyczne w zależności informacyjnej. Mniejszości te zarzucają mediom państwowym, że są jednostronne, nieobiektywne i skoncentrowane na sprawach dotyczących etnicznej większości, a Rosję i mniejszość rosyjskojęzyczną postrzega jako źródło konfliktu. Media łotewskie dużo rzadziej prezentują tematy, które interesują rosyjskojęzycznych mieszkańców. Dyskurs dotyczący tożsamości politycznej (obywatelskiej) jest nieobecny w obu językach. Nieobecny jest także dialog między grupami etnicznymi, najczęściej pojawiają się wzajemne oskarżenia i brak zaufania. Duże znaczenie mają portale informacyjne w języku rosyjskim: Vesti.lv, Sputnik.lv, Rubaltic.ru, Ves.lv, Press.lv, reprezentujące narrację prokremlowską. Negatywnie oceniają politykę Łotwy, obwiniając władzę o dyskryminację osób rosyjskojęzycznych w tym państwie. Grupą docelową są młodzi ludzie korzystający z portali internetowych i mediów społecznościowych, które pozwalają na szybki dostęp do informacji, interakcję z innymi użytkownikami oraz anonimowość.

Popularność mediów rosyjskojęzycznych na Łotwie powoduje, że mniejszości żyją w izolacji od większości społeczeństwa, są słabo zintegrowane i tworzą odrębne od łotewskiego społeczeństwo informacyjne [Rozukalne 2016]. Na przykład wiele osób we wschodnich regionach Łotwy nie ma dostępu do cyfrowych mediów w języku państwowym, dobrze odbiera za to telewizję z Rosji i Białorusi. Odsetek osób korzystających jednocześnie z różnych alternatywnych źródeł informacji (czytających prasę lub oglądających telewizję w językach rosyjskim i narodowym) jest niewielki. Dodatkowo media rosyjskojęzyczne są efektywnym kanałem komunikacji między społeczeństwem rosyjskojęzycznym a partiami i organizacjami działającymi na rzecz Rosjan na Łotwie oraz promującym wizję i politykę Rosji [Kirwiel 2017].

Podobnie jak na Łotwie, w Estonii środowisko informacyjne jest głęboko podzielone, nie tylko ze względu na język transmisji [Dougherty, Kaljurand 2015]. Mimo że w kanałach telewizji estońskiej niektóre programy są nadawane po 
rosyjsku (lub z podpisami w języku rosyjskim), mniejszość rosyjskojęzyczna najchętniej ogląda rosyjskie prokremlowskie giganty medialne: RT i Sputnik. Są też lokalne media rosyjskojęzyczne o zasięgu regionalnym. Estońska rosyjskojęzyczna telewizja ETV+ początkowo odnosiła sukcesy, jednak trudno jej konkurować z telewizją z Rosji, która cieszy się dużą popularnością i oglądalnością. W rosyjskojęzycznych mediach publicznych w Estonii mniej czasu poświęca się sprawom rosyjskim, a ton wypowiedzi w kwestiach polityki Estonii lub relacji z Rosją jest łagodniejszy [Parshukov 2017]. Na rynku dostępna jest rosyjskojęzyczna prasa: „Moskovskij Komsomolec” - Estonia (Московский Комсомолеи - Эстония) i „Delovye Vedomostii” (Деловые Ведомости). „Komsomolskaya Pravda v Baltii" (Комсомольская Правда в Балтии) jest gazetą wydawaną w Tallinie, dystrybuowaną w Estonii, Łotwie i Finlandii, w nakładzie 5-12 tys. sztuk. Od 2008 r. w Estonii odbywają się także spotkania informacyjne w ramach klubu Impressum organizowane przez dziennikarzy powiązanych z gazetą „Komsomolskya Pravda". W 2015 r. Estonia odmówiła przyjazdu i udziału w spotkaniu Impressum włoskiego dziennikarza Gulietto Chiesa, sympatyzującego z Rosją i otwarcie popierającego aneksję Krymu ${ }^{1}$. We wschodnich regionach większość tytułów prasowych ukazuje się w języku rosyjskim („Narva”, „Narvskaya Gazeta”, „Viru Prospekt”, „Narvskiy Rabochiy”). Najpopularniejszy tygodnik „Gorod” (Город) jest dostępny bezpłatnie w Narwie i jej sąsiedztwie. Rzetelna, dobra informacja jest kosztowna, dlatego sukcesywnie spadają nakłady prasy rosyjskojęzycznej [Jõesaar, Rannu, Jufereva 2013]. W 2009 r. zamknięto m.in. wysokonakładową „Molodozh' Estonii” (Молодёэь Эстонии), a w 2016 r. - „Den’ za Dnem” (День за Днем). Postimees ograniczono do wydawnictwa online. Za oficjalne powody uznano przyczyny społeczno-ekonomiczne: spadek czytelnictwa drukowanego oraz wzrost zainteresowania źródłami online, jednak część odbiorców uważa, że to kolejny krok elit narodowych skierowany przeciwko językowi rosyjskiemu w Estonii. Media stawiają więc na tanią, emocjonalną, prostą i rozrywkową informację, dostępną online. Wśród portali informacyjnych uwagę zwraca Baltnews kierowany przez Aleksandra Kornilova, członka Rady Koordynacyjnej Rosyjskiej Diaspory, a oficjalnie finansowany przez spółkę z Holandii.

$\mathrm{Na}$ Litwie media rosyjskojęzyczne są mniej popularne, jednak produkcje rosyjskie pojawiają się na kanałach litewskich [Maliukevičius 2015]. PBK proponuje widzom lokalne programy (m.in. „Litovskoye vremia”). Działają portale informacyjne Sputniknews.lt i Baltnews.lt, których odbiorcami są również osoby polskiego pochodzenia. Dlatego w ostatnich latach portale te poświęciły znaczną uwagę problemom i statusowi polskiej mniejszości narodowej w regionie wileńskim oraz konfliktom polsko-litewskim. Publikacje starały się przekonać

1 Na spotkaniu klubu dyskusyjnego, który odbył się w Kaliningradzie 20 kwietnia 2018 r., Chiesa stwierdził, że władze państw bałtyckich zostały wybrane i przeszkolone przez tajne służby amerykańskie, a w wyniku uzyskania niepodległości państwa bałtyckie stały się de facto kolonią Stanów Zjednoczonych Ameryki [Baltnews 2018]. 
odbiorców, że Litwa dyskryminuje miejscowych Polaków oraz, że Polska nie zrzeka się roszczeń terytorialnych wobec swoich sąsiadów. Niszowe alternatywne media społecznościowe zarządzane przez liderów prokremlowskich NGO działających na Litwie są oskarżane o rozprzestrzenianie treści korzystnych dla Rosji [State Security Department... 2018]. Rosyjskojęzyczne media na Litwie promują NATO- i eurosceptycyzm, jednak ich efektywność i możliwości poszerzenia grona odbiorców są ograniczone. Dodatkowo Litwa prowadzi bardziej restrykcyjną politykę informacyjną w porównaniu do Łotwy i Estonii.

\section{INFOTAINMENT I DEZINFORMACJA}

Wysoka pozycja PBK, znaczny udział prasy rosyjskojęzycznej na Łotwie oraz zauważalny wzrost odbiorców portali informacyjnych w ostatnich latach w omawianych trzech państwach są wynikiem popularności treści audiowizualnych i rozrywkowych jako źródło informacji [Krūtaine, Loit, Staselis, Puriņa 2017]. Media powołują się na znane autorytety, aby uwiarygodnić przekaz (choć sami autorzy tekstów często pozostają anonimowi). Prezenterzy telewizyjni są atrakcyjni, elokwentni, dobrze ubrani. Krótkie, chwytliwe informacje, nieformalny język, uproszczenia i generalizacje ułatwiają zapamiętywanie. Niezwykłość obrazu, tragedia i sensacja pobudzają emocje odbiorcy. W mediach nie ma tematów tabu, zdecydowanie i ze stanowczością informują „o tym, o czym inni milczą" ". Polityczny infotainment stał się egalitarny, zrozumiały i dostępny dla masowych odbiorców [Novikova 2014]. Wysoka oglądalność mediów wynika $\mathrm{z}$ atrakcyjności wizualnej i najnowszych technologii, tj. dobrze zorganizowanej strony internetowej, przykuwających uwagę haseł, platform VIDEO, transmisji dźwięków i obrazów dobrej jakości, szybkości przekazu. Dynamika treści i natychmiastowość komunikatów odpowiadają intensywności zjawisk otaczającej rzeczywistości oraz nie pozostawiają czasu odbiorcy na pogłębioną refleksję. Przekaz jest dostosowany do konkretnych grup docelowych i do ich potrzeb [Podobas 2011]. Młodych odbiorców przyciągają spersonalizowany komunikat, social media, blogi i możliwość komentowania zjawiska, która ułatwia ciągłą interakcję. Funkcja ta pozwala odbiorcom przedstawiać ich własne stanowisko i kształtować ich przekonanie, że są włączeni w proces tworzenia dyskursu informacyjnego [Antczak, Plashkina 2017].

Informacja jest produktem, dobrem konsumpcyjnym, towarem do sprzedaży, nie służy wyłącznie celom informacyjnym. Rosja wykorzystuje informację jako narzędzie w realizacji jej interesów w państwach bałtyckich, w celu wpłynięcia na odbiorców rosyjskojęzycznych, zdestabilizowania sytuacji wewnętrznej państw bałtyckich, zdyskredytowania ich rządów narodowych, osłabienia spójności wewnętrznej Europy (krytyka UE i NATO), wzniecenia konfliktów społecznych

\footnotetext{
2 „Говорим то, о чем другие молчат” - hasło promujące Sputnik.
} 
i kreowania pozytywnego obrazu Rosji (tab. 1). Media rosyjskojęzyczne są częścią strategii informacyjnej Rosji [Kuczyńska-Zonik 2016]. Odpowiadają również potrzebom informacyjnym grupy docelowej, która obwinia rządy narodowe Litwy, Łotwy i Estonii za swój status społeczno-ekonomiczny, utożsamia się z Rosją i jest podatna na hasła populistyczne i propagandowe ze strony Rosji.

Tabela 1. Media rosyjskojęzyczne w państwach bałtyckich

\begin{tabular}{|c|c|c|c|c|}
\hline Narracja & Cel & Metody & Państwa & Przykłady \\
\hline $\begin{array}{l}\text { Euro-scepty- } \\
\text { cyzm }\end{array}$ & $\begin{array}{l}\text { Podziały spo- } \\
\text { łeczne }\end{array}$ & \begin{tabular}{|l|} 
Dobrobyt \\
republik \\
w okresie \\
sowieckim \\
oraz nie- \\
równości \\
społeczne \\
spowodowa- \\
ne wejściem \\
do UE
\end{tabular} & \begin{tabular}{|l} 
Zwłasz- \\
cza \\
Łotwa \\
i Litwa
\end{tabular} & $\begin{array}{l}\text { Sputnik informował, że Łotwa } \\
\text { trwoni pieniądze z funduszy UE. } \\
\text { Komentując debatę dotyczącą Nord } \\
\text { Stream 2, powoływał się na rosyj- } \\
\text { skich ekspertów, którzy ostrzega- } \\
\text { ją, że przeciwnicy budowy Nord } \\
\text { Stream będą próbowali wykorzystać } \\
\text { wszystkie możliwe narzędzia, aby } \\
\text { opóźnić budowę gazociągu }\end{array}$ \\
\hline $\begin{array}{l}\text { Sceptycyzm } \\
\text { wobec } \\
\text { NATO }\end{array}$ & $\begin{array}{l}\text { Osłabienie spój- } \\
\text { ności wewnętrz- } \\
\text { nej NATO, } \\
\text { wzrost poczucia } \\
\text { zagrożenia ze } \\
\text { strony NATO, } \\
\text { osłabienie sto- } \\
\text { sunków z USA }\end{array}$ & $\begin{array}{l}\text { Protest prze- } \\
\text { ciwko obec- } \\
\text { ności NATO } \\
\text { w regionie }\end{array}$ & $\begin{array}{l}\text { Litwa, } \\
\text { Łotwa, } \\
\text { Estonia }\end{array}$ & $\begin{array}{l}\text { W styczniu } 2017 \text { r. w rosyjskiej sta- } \\
\text { cji telewizyjnej Rossiya } 24 \text { skomen- } \\
\text { towano obecność wojsk NATO na } \\
\text { Łotwie jako kosztowne i bezcelowe. } \\
\text { W tym samym czasie prokremlow- } \\
\text { ski portal Newsbalt.ru opublikował } \\
\text { artykuł, z którego wynikało, że } \\
\text { obecność żołnierzy sojuszu na Li- } \\
\text { twie oznacza okupację Litwy przez } \\
\text { Zachód }\end{array}$ \\
\hline $\begin{array}{l}\text { Stosunki } \\
\text { z USA }\end{array}$ & $\begin{array}{l}\text { Dyskredytowa- } \\
\text { nie elit narodo- } \\
\text { wych, podziały } \\
\text { społeczne }\end{array}$ & $\begin{array}{l}\text { Oskarżanie } \\
\text { o służalczość } \\
\text { państw } \\
\text { bałtyckich } \\
\text { wobec USA }\end{array}$ & $\begin{array}{l}\text { Litwa, } \\
\text { Łotwa, } \\
\text { Estonia }\end{array}$ & $\begin{array}{l}\text { Sputnik skomentował, że w zamian } \\
\text { za współpracę z „nieprzewidywal- } \\
\text { nym” Donaldem Trumpem i jego } \\
\text { pomoc w ochronie przed Rosją pań- } \\
\text { stwa bałtyckie będą musiały zwięk- } \\
\text { szyć wydatki w NATO i zakupić } \\
\text { sprzęt wojskowy od USA. Dodatko- } \\
\text { wo państwa bałtyckie ze względu na } \\
\text { „absolutnie nieelastyczną pozycją } \\
\text { na peryferiach europejskiej polity- } \\
\text { ki” stoją na przeszkodzie stabilizacji } \\
\text { stosunków rosyjsko-zachodnich }\end{array}$ \\
\hline $\begin{array}{l}\text { Stosunki } \\
\text { z ZSRR/ } \\
\text { Rosją }\end{array}$ & $\begin{array}{l}\text { Podziały spo- } \\
\text { teczne, dyskre- } \\
\text { dytowanie elit } \\
\text { narodowych na } \\
\text { arenie między- } \\
\text { narodowej }\end{array}$ & $\begin{array}{l}\text { Oskarżanie } \\
\text { o rusofobię }\end{array}$ & $\begin{array}{l}\text { Zwłasz- } \\
\text { cza Li- } \\
\text { twa, także } \\
\text { Łotwa, } \\
\text { Estonia }\end{array}$ & $\begin{array}{l}\text { Na portalu Русский мир (Russkij } \\
\text { mir) pojawił się wywiad z francu- } \\
\text { skim dziennikarzem Dimitrim de } \\
\text { Koshko, który wyjaśnił, że rusofo- } \\
\text { bia stała się elementem spajającym } \\
\text { UE, a prym w tej kwestii wiodą pań- } \\
\text { stwa bałtyckie }\end{array}$ \\
\hline
\end{tabular}




\begin{tabular}{|c|c|c|c|c|}
\hline Narracja & Cel & Metody & Państwa & Przykłady \\
\hline $\begin{array}{l}\text { Stosunki } \\
\text { z ZSRR/ } \\
\text { Rosją }\end{array}$ & $\begin{array}{l}\text { Promocja pozy- } \\
\text { tywnego obrazu } \\
\text { Rosji }\end{array}$ & $\begin{array}{l}\text { Rosja jako } \\
\text { alternatywa } \\
\text { dla rządów } \\
\text { narodowych } \\
\text { i ideologii } \\
\text { zachodniej }\end{array}$ & $\begin{array}{l}\text { Zwłasz- } \\
\text { cza } \\
\text { Łotwa, } \\
\text { Estonia }\end{array}$ & $\begin{array}{l}\text { Sputnik poinformował, że mimo } \\
\text { nasilonej zachodniej propagandy } \\
\text { większość mieszkańców państw } \\
\text { bałtyckich jest pozytywnie nasta- } \\
\text { wiona do Rosji i popiera współpracę } \\
\text { ze wschodnim sąsiadem }\end{array}$ \\
\hline \multirow[t]{4}{*}{$\begin{array}{l}\text { Polityka } \\
\text { pamięci }\end{array}$} & $\begin{array}{l}\text { Podziały spo- } \\
\text { łeczne }\end{array}$ & $\begin{array}{l}\text { Promocja ro- } \\
\text { syjskiej wizji } \\
\text { II wojny } \\
\text { światowej, } \\
\text { nostalgia za } \\
\text { ZSRR }\end{array}$ & $\begin{array}{l}\text { Łotwa, } \\
\text { Estonia, } \\
\text { w mniej- } \\
\text { szym } \\
\text { stopniu } \\
\text { Litwa }\end{array}$ & $\begin{array}{l}\text { Na stronie RuBaltic pojawiła się } \\
\text { informacja, że zakaz propagowania } \\
\text { symboli sowieckich oraz dyskredy- } \\
\text { tacja ZSRR wynika z lęków państw } \\
\text { bałtyckich. W rzeczywistości Rosja } \\
\text { nie stanowi dla nich żadnego za- } \\
\text { grożenia. Ponadto portal podał, że } \\
\text { Związek Radziecki miał wyższy po- } \\
\text { ziom bezpieczeństwa i zabezpiecze- } \\
\text { nia społecznego niż obecne państwa } \\
\text { bałtyckie }\end{array}$ \\
\hline & $\begin{array}{l}\text { Dyskredytowa- } \\
\text { nie elit narodo- } \\
\text { wych, podziały } \\
\text { społeczne }\end{array}$ & $\begin{array}{l}\text { Oskarżanie } \\
\text { o fałszowa- } \\
\text { nie historii, } \\
\text { nielegalne } \\
\text { usuwanie } \\
\text { pomników } \\
\text { sowieckich } \\
\end{array}$ & $\begin{array}{l}\text { Lotwa, } \\
\text { Estonia }\end{array}$ & \multirow{3}{*}{$\begin{array}{l}\text { Sputnik powołał się na słowa rzecz- } \\
\text { niczki rosyjskiego MSZ Marii Za- } \\
\text { charowej o tym, że przez usuwanie } \\
\text { pomników żołnierzy radzieckich } \\
\text { państwa bałtyckie starają się „oczyś- } \\
\text { cić pole informacyjne” oraz rozpo- } \\
\text { wszechniają zniekształcony obraz } \\
\text { historii }\end{array}$} \\
\hline & $\begin{array}{l}\text { Destabilizacja } \\
\text { wewnętrzna, } \\
\text { postawy anty- } \\
\text { rządowe }\end{array}$ & $\begin{array}{l}\text { Oskarżanie } \\
\text { o nieudol- } \\
\text { ność, niede- } \\
\text { mokratycz- } \\
\text { ność rządów } \\
\text { narodowych }\end{array}$ & $\begin{array}{l}\text { Zwłasz- } \\
\text { cza Ło- } \\
\text { twa i Li- } \\
\text { twa, także } \\
\text { Estonia }\end{array}$ & \\
\hline & $\begin{array}{l}\text { Dyskredytowa- } \\
\text { nie elit narodo- } \\
\text { wych na arenie } \\
\text { międzynarodo- } \\
\text { wej }\end{array}$ & $\begin{array}{l}\text { Oskarżanie } \\
\text { o dyskry- } \\
\text { minację } \\
\text { mniejszości } \\
\text { narodowych } \\
\text { i etnicznych, } \\
\text { powoły- } \\
\text { wanie się } \\
\text { na raporty } \\
\text { instytucji } \\
\text { międzynaro- } \\
\text { dowych i po- } \\
\text { wszechnie } \\
\text { uznawanych } \\
\text { NGO }\end{array}$ & $\begin{array}{l}\text { Łotwa, } \\
\text { Estonia }\end{array}$ & \\
\hline
\end{tabular}




\begin{tabular}{|c|l|l|l|l|}
\hline \multicolumn{1}{|c|}{ Narracja } & \multicolumn{1}{|c|}{ Cel } & \multicolumn{1}{c|}{ Metody } & Państwa & \multicolumn{1}{c|}{ Przykłady } \\
\hline $\begin{array}{l}\text { Polityka } \\
\text { wewnętrzna }\end{array}$ & $\begin{array}{l}\text { Dyskredytowa- } \\
\text { nie elit narodo- } \\
\text { wych na arenie } \\
\text { międzynarodo- } \\
\text { wej, podziały } \\
\text { społeczne }\end{array}$ & $\begin{array}{l}\text { Oskarżenie } \\
\text { o ignorowa- } \\
\text { nie prawa } \\
\text { międzyna- } \\
\text { rodowego } \\
\text { przez rządy } \\
\text { (status nie- } \\
\text { obywatela) }\end{array}$ & $\begin{array}{l}\text { Lotwa, } \\
\text { Estonia }\end{array}$ & $\begin{array}{l}\text { We wrześniu 2014 r. Konstantin } \\
\text { Dolgov, komisarz ds. praw człowie- } \\
\text { ka, demokracji i rządów prawa przy } \\
\text { rosyjskim MSZ spotkał się z przed- } \\
\text { stawicielami mniejszości rosyjsko- } \\
\text { języcznych Litwy, Lotwy i Estonii } \\
\text { w Rydze. Dolgov skrytykował rzą- } \\
\text { dy państw bałtyckich, które traktują } \\
\text { osoby rosyjskojęzyczne jako „oby- } \\
\text { wateli drugiej kategorii” }\end{array}$ \\
\cline { 3 - 5 } & $\begin{array}{l}\text { Oskarżenie } \\
\text { o łamanie } \\
\text { wolności } \\
\text { słowa }\end{array}$ & $\begin{array}{l}\text { Lotwa, } \\
\text { Litwa }\end{array}$ & $\begin{array}{l}\text { W 2014 r., Konstantin Dolgov na } \\
\text { swoim Twitterze określił ogranicze- } \\
\text { nia dla rosyjskiej telewizji RTR na } \\
\text { Łotwie jako cenzorowanie informa- } \\
\text { cji i łamanie fundamentalnych praw } \\
\text { dostępu do mass mediów. W podob- } \\
\text { nym tonie wypowiadali się dzienni- } \\
\text { karze na łamach Sputnika }\end{array}$ \\
\hline
\end{tabular}

Źródło: Autor.

Przekaz informacyjny w mediach rosyjskojęzycznych jest dostosowany do uwarunkowań politycznych oraz specyfiki odbiorców na Litwie, Łotwie i w Estonii, dlatego narracje w mediach różnią się w zależności od państwa. Spośród trzech państw bałtyckich władze Litwy są najbardziej krytyczne wobec Rosji. W związku z tym w mediach rosyjskojęzycznych w tym państwie dominuje narracja eurosceptycyzmu oraz negacji wobec USA i NATO w celu osłabienia związku Litwy ze światem zachodnim. $Z$ jednej strony władze są oskarżane o rusofobię, a z drugiej - budowana jest koalicja mniejszości polskiej i rosyjskojęzycznej w celu dyskredytacji elit narodowych i osłabienia spójności społecznej. Na Łotwie i w Estonii z powodu licznej mniejszości rosyjskojęzycznej częściej pojawia się pozytywny obraz Rosji. Promowana jest rosyjska wizja historii. W kierunku rządów narodowych jest kierowana krytyka wspierania neonazizmu i neofaszy$\mathrm{zmu}^{3}$ oraz fałszowanie historii (w związku z usunięciem pomnika „Brązowego Żołnierza” z centrum Tallina w 2007 r.). Działania dotyczące promocji wartości historycznych i tradycji patriotycznych można interpretować w kontekście potrzeby zabezpieczenia interesów w rosyjskiej strefie wpływów oraz tworzenia wspólnoty tzw. Русский мир (Świat rosyjski). Dodatkowo rządy omawianych państw są oskarżane o dyskryminację mniejszości i pozbawianie ich praw politycznych i kulturowych. Wzmacniane są podziały etniczne, osłabiana spójność

3 Nawiązanie do marszu weteranów łotewskich oddziałów Waffen SS, które walczyły z wojskami sowieckimi podczas II wojny światowej, i ich sympatyków, zwykle członków łotewskich organizacji nacjonalistycznych. Wydarzenie odbywa się w Rydze 16 marca - w rocznicę bitwy nad rzeką Wieliką w obwodzie pskowskim z armią radziecką w 1944 r. 
społeczna, zwłaszcza na płaszczyźnie ekonomicznej, budowane jest przekonanie o społecznym dobrobycie w ZSRR.

Największe znaczenie $\mathrm{w}$ działaniach propagandowych ma telewizja i Internet, wzrasta znaczenie mediów społecznościowych. W mediach dominuje przekaz negatywny: krytyka Zachodu (NATO, UE) i narodowych elit w państwach bałtyckich [Mozers 2007]. Media rosyjskojęzyczne opisujące zdarzenia organizowane przez radykalne ultraprawicowe ruchy narodowe dowodzą popularności ekstremistycznych ideologii (neonazistowskich) wspieranych przez rządy państw bałtyckich. Promocja rosyjskich wartości i kultury ma charakter drugorzędny, przy czym aprobata dla polityki Władimira Putina nie zawsze jest jednoznaczna i wyartykułowana. Media odwołują się do historii i symboli, tworzą mity i iluzje, sakralizują obraz Związku Radzieckiego. Tropy sowieckie pojawiają się w przywołaniach historii życia indywidualnych ludzi, pozwalających utożsamiać się ze „Zwykłymi obywatelami”, a także znaków i przedstawień upamiętniających i gloryfikujących wydarzenia z przeszłości. I tak, pamiątkowe 5-rublowe monety z kolekcji „Miasta - stolice państw wyzwolone przez wojska sowieckie od okupantów niemiecko-faszystowskich", wypuszczone w 2016 r. przez Bank Centralny Federacji Rosyjskiej stały się okazją do przypomnienia „prawdziwej historii” państw bałtyckich. Na monetach znalazły się m.in. rzeźby z okresu sowieckiego z Estonii, Litwy i Łotwy oraz daty „wyzwolenia” miast: Tallina - 22.09.1944 r.; Wilna - 13.07.1944 r. i Rygi - 15.10.1944 r.

Zdaniem Rosji na terenie republik bałtyckich w 1940 r. nie miały miejsca żadne działania wojenne, a włączenie ich w ZSRR dokonało się na mocy dobrowolnych porozumień z rządami tych państw. Dodatkowo w okresie tym w bałtyckich republikach sowieckich władzę sprawowały instytucje narodowe, co ma zaprzeczać rzekomej okupacji ze strony ZSRR. W tym samym tonie na łamach m.in. Sputnika i Baltnews.lt relacjonowano marsz „Nieśmiertelnego pułku” sentymentalnego pochodu weteranów Wielkiej Wojny Ojczyźnianej i ich rodzin niosących portrety swoich bliskich, odwołujących się do tradycyjnych wartości: państwa, honoru i rodziny. Te kulturowe prowokacje wyzwalają emocje odbiorców (osób rosyjskojęzycznych) i władz narodowych Litwy, Łotwy i Estonii, powodując chaos informacyjny i wzajemne oskarżenia, a w rezultacie napięcia i pogłębienie konfliktów społecznych.

Media tworzą wizję pożądanej przyszłości. Wyimaginowany obraz „lepszego świata" pozwala przetrwać osobom, które z powodu pochodzenia i języka nierzadko zmagają się z niskim statusem społecznym i ekonomicznym [Kuczyńska-Zonik 2017]. Narracja medialna koncentruje się na utrzymywaniu znacznych podziałów etnicznych w społeczeństwie oraz wzajemnego braku zaufania wobec grup społecznych w państwie. Wpływa to na stopień stabilności politycznej, społecznej i kulturowej państwa. Szczególnym przypadkiem jest Łotwa, gdzie podziały na linii etnicznej są największe; w nieco mniejszym stopniu problem dezinformacji dotyczy Estonii, gdzie społeczeństwo jest bardziej świadome zagrożeń informacyjnych, a polityka państwa - bardziej otwarta i liberalna. Techniki manipulacji są 
różnorodne: pojawiają się uproszczenia poznawcze, podział na my-oni (tworzenie wizerunku wroga), teorie konspiracyjne. Język jest emocjonalny (język perswazji lub negacji), napastliwy i agresywny.

\section{KONKLUZJE}

Zwolennicy komercjalizacji informacji podkreślają znaczenie infotainment w demokratyzacji debaty publicznej. Przestępność i łatwość odbioru informacji wpływa na jej dostępność i kształtuje alternatywne środowiska informacyjne. Prostota przekazu ułatwia zrozumienie skomplikowanych tematów politycznych masowym odbiorcom. Ich przeciwnicy zwracają uwagę na trywializację i marginalizację informacji, obniżenie jakości dyskursu publicznego, a w efekcie deformację i manipulację informacją. W tym znaczeniu infotainment jest zaprzeczeniem demokracji, gdyż obniża zdolność i potrzebę refleksji, upraszcza obraz i fałszuje rzeczywistość. Propaganda, manipulacja i dezinformacja stały się bardziej agresywne w związku z aneksją Krymu przez Rosję. Jednocześnie państwa bałtyckie podjęły działania przeciwko wzmożonemu wpływowi informacyjnemu. W 2015 r. rosyjskojęzyczny kanał RTR Planeta na Litwie został zawieszony na trzy miesiące z powodu propagowania nienawiści między narodem ukraińskim a rosyjskim. Już wcześniej, w 2014 r., taką samą karę otrzymał NTV z powodu fałszywego przekazu o działaniach Armii Sowieckiej na Litwie w 1991 r. Podobnie Łotwa w 2014 r. oraz w 2016 r. wprowadziła ograniczenia dla RTR Planeta z powodu przekazywania fałszywych informacji na temat aneksji Krymu i wojny na Ukrainie, a w 2016 r. łotewski Sputnik utracił prawo do korzystania z domeny .lv w związku z oskarżeniem o propagandę i dezinformację. Państwa bałtyckie starają się także kształtować otwarte, dojrzałe, niezależne środowisko informacyjne dostępne dla osób rosyjskojęzycznych. W 2015 r. Estonia rozpoczęła nadawanie rosyjskojęzycznego kanału ETV+. Obecnie ma bardzo niewielką oglądalność, trudno mu konkurować z mediami rosyjskimi. Przypuszcza się, że w przyszłości może sprzyjać nie tylko integracji społeczności rosyjskojęzycznej w Estonii, ale także inicjować wzajemne kontakty i wzbudzać tolerancję i zaufanie między narodami rosyjskim i estońskim. Podobne propozycje utworzenia rosyjskojęzycznego kanału LTV pojawiły się w 2015 r. na Łotwie, jednak nie zostały zaaprobowane przez rząd, który obawiał się zwiększenia użycia języka rosyjskiego w przestrzeni medialnej Łotwy [Dimantas 2016].

Popularność języka rosyjskiego, pozytywny stosunek do kultury rosyjskiej i symboli, a także nostalgia i sowieckie resentymenty kształtują korzystne warunki dla rosyjskojęzycznego środowiska informacyjnego w państwach bałtyckich. Szczególnym rodzajem przekazu jest infotainment jako przykład zastosowania elementów kultury zachodniej [Meister 2016] lub szerzej - globalnej (global infotainment) [Thussu 2007], polegający na wykorzystaniu nowych metod i instrumentów wzmacniających dotychczasowe wzorce kulturowe i społeczne kon- 
strukcje. Nowy rodzaj infotainment wspomaga propagandę rosyjską w państwach bałtyckich w realizacji celów obecnych władz Rosji, przez destabilizowanie sytuacji wewnętrznej państw bałtyckich, dyskredytowanie ich elit, wspieranie postaw antyrządowych, wzniecanie konfliktów społecznych oraz promowanie pozytywnego obrazu Rosji.

Strategia informacyjna Rosji wobec państw bałtyckich jest efektywna, a połączenie infotainment i dezinformacji przynosi rezultaty. Media rosyjskojęzyczne pełnią rolę instytucji politycznych nastawionych na maksymalizację politycznego zysku. Mniejszości rosyjskojęzyczne są sceptyczne wobec informacji, przestały dowierzać mediom (zarówno tym rosyjskojęzycznym, jak i w językach narodowych Litwy, Łotwy i Estonii), wzrasta chaos informacyjny. Mimo że szeroki dostęp do różnych źródeł informacji umożliwia weryfikację przekazu, nie wpływa to na poziom oglądalności mediów rosyjskojęzycznych, gdyż programy te są zdecydowanie bardziej interesujące i przyciągające uwagę odbiorców niż programy rodzimej produkcji. Wysoka konkurencyjność, fragmentaryzacja i komercjalizacja rynku medialnego powodują nastawienie mediów na zaspokajanie potrzeb odbiorców. Dlatego koncentrują się one na sprawach w regionie i problemach, które bezpośrednio dotyczą widzów. Jednocześnie kulturowe utożsamianie się z Rosją nie oznacza bezrefleksyjnej aprobaty dla polityki Putina. Tożsamość obywatelska (civil identity) może być kształtowana niezależnie od tożsamości kulturowej (cultural identity) [Zimmer 2003], funkcjonować równolegle, dopełniać lub wykluczać drugą tożsamość. Chociaż osoby rosyjskojęzyczne są lojalne wobec państwa, w którym przebywają, akceptują symbole narodowe i wartości polityczne, chcą zachować język, tradycję i rosyjską narrację historyczną. Przy intensyfikacji prokremlowskiej dezinformacji i negacji postaw obywatelskich w państwach bałtyckich kryzys tożsamościowy u osób rosyjskojęzycznych może się pogłębiać.

Title: Infotainment and Disinformation in Russian-Speaking Media in the Baltic States

Summary: A paper deals with an information discourse in the Baltic states with particular emphasis on Russian-speaking media influenced by Russia. The aim of the research is to show information in manipulation and disinformation campaign. My point of departure is that currently an information crisis in the Baltic states results from the process of shaping a new type of infotainment that effectively absorbs the attention of Russian-speaking audiences in the Baltic states and strengthens and sacralizes narratives regarding Russia's position and its interests in the international environment.

Keywords: infotainment, disinformation, the Baltic states, Russia 


\section{BIBLIOGRAFIA}

1. Antczak A., Plashkina I. (2017), Propaganda. Rosyjski dyskurs komunikowania politycznego w przekazie telewizyjnym stacji Pierwyj kanat, Toruń.

2. Birka I. (2016), Expressed attachment to Russia and social integration: the case of young Russian speakers in Latvia, 2004-2010, "Journal of Baltic Studies", vol. 47, nr 2, s. 219-238. DOI: https://doi.org/10.1080/01629778.2015.1094743.

3. Baltnews (2018), Джульетто Кьеза: в попытках получить независимость от России Прибалтика стала колонией США, 22.04.2018, Baltnews.ee, http://baltnews.ee/policy/20180422/1016634449.html [dostęp: 21.05.2018].

4. BNS (2014), Italian journalist Chiesa ordered to leave Estonia, 16.12.2014, Postimees.ee, http://news.postimees.ee/3028421/italian-journalist-chiesa-ordered-to-leave-estonia [dostęp: 17.04.2018].

5. Darczewska J. (2014), Anatomia rosyjskiej wojny informacyjnej. Operacja krymska - studium przypadku, Ośrodek Studiów Wschodnich (OSW), https://www.osw.waw.pl/sites/default/files/ anatomia_rosyjskiej_wojny_informacyjnej.pdf [dostęp: 17.04.2018].

6. Demers D. (2005), Dictionary of Mass Communication and Media Research: A Guide for Students, Scholars and Professionals, Washington State University, Spokane.

7. Dimants A. (2016), Latvian public service broadcasting (PSB) at a media policy crossroads on the path to public service media (PSM), ,Środkowoeuropejskie Studia Polityczne”, nr 2, s. $155-165$.

8. Dougherty J., Kaljurand R. (2015), Estonia's "Virtual Russian World”: The Influence of Russian Media on Estonia's Russian Speakers, International Centre for Defence and Security, Tallin.

9. Goban-Klas T. (2011), Tabloidyzacja mediów a neopopulizm, [w:] Media-Populizm - Demokracja, R. Chytrowski (red.), Wrocław, s. 13-25.

10. Jõesaar A., Rannu S., Jufereva M. (2013), Media for the minorities: Russian language media in Estonia 1990-2012, "Media Transformations", vol. 9, s. 118-154. DOI: https://doi. org/10.7220/2029-865X.09.07.

11. Kirwiel E. (2017), Internet jako narzędzie komunikacji partii politycznych w Federacji Rosyjskiej, [w:] Komunikowanie polityczne, E. Maj, E. Podgajna, A. Szwed-Walczak, Ł. Jędrzejski (red.), Lublin, s. 301-311.

12. Krūtaine A., Loit U., Staselis R., Purina E. (2017), Baltic Media Health Check 2015-2016, The Centre for Media Studies at SSE, Ryga.

13. Kuczyńska-Zonik A. (2017), Integration of Russian-speakers in the Baltic states, „Myśl Ekonomiczna i Polityczna", nr 3, s. 228-250.

14. Kuczyńska-Zonik A. (2016), Russian propaganda-methods of influence in the Baltic States, „Rocznik Instytutu Europy Środkowo-Wschodniej” Special Issue: Information Security in East-Central Europe, vol. 14, nr 2, s. 43-59.

15. Langman L. (2015), Infotainment, [w:] The Wiley Blackwell Encyclopedia of Consumption and Consumer Studies, D. Thomas Cook, J.M. Ryan (red.).

16. Laruelle M. (2015), The 'Russian World'. Russia's Soft Power and Geopolitical Imagination. Center on Global Interests.

17. Muižnieks N. (red.) (2010), How Integrated Is Latvian Society? An Audit of Achievements, Failures and Challenges, Ryga.

18. Maliukevičius N. (2015), Tools of Destabilization': Kremlin's Media Offensive in Lithuania, "Journal on Baltic Security", vol. 1, nr 1, s. 117-126. DOI: https://doi.org/10.1515/jobs-20160003. 
19. Meister S. (2016), Isolation and Propaganda The Roots and Instruments of Russia's Disinformation Campaign, Waszyngton.

20. Mozers M. (2007), Latvian media identity and diversity, "Filosofija. Sociologija", vol. 18, nr 4, s. 91-94.

21. Novikova A.A. (2014), Infotainment on Russian TV as a tool of desacralization of Soviet myths and creation of a myth about the future, "Revista Científica de Información y Comunicación", vol. 11, s. 229-244.

22. Nowak E. (2009), Komercjalizacja komunikacji politycznej-infotainment i politainment w programach informacyjnych, „Annales Universitatis Mariae Curie-Skłodowska. Sectio K, Politologia", vol. 16, nr 2, s. 201-213.

23. Ozoliņa Ž. (red.) (2016), Societal Security. Inclusion-Exclusion Dilemma. A portrait of the Russian-speaking community in Latvia, Zinātne Publishers.

24. Parshukov V. (2017), Media, Memory, and Minority: The Russian Language TV Channel ETV+ and its Role in the Long-Lasting "War of Memories" in Estonia, praca magisterska, Tartu.

25. Podobas I. (2011), Public relations jako narzędzie kreowania wizerunku partii politycznych, Warszawa.

26. Pomerantsev P. (2015), The Kremlin's Information War, "Journal of Democracy", vol. 26, nr 4, s. 40-50. DOI: https://doi.org/10.1353/jod.2015.0074.

27. Postman N. (1985), Amusing Ourselves to Death, Viking Penguin, Nowy Jork.

28. Rozukalne A. (2016), 'All the Necessary Information is Provided by Russia 's Channels'. Russian-language Radio and TV in Latvia: Audiences and Content, "Baltic Screen Media Review", vol. 4, s. 106-124. DOI: https://doi.org/10.1515/bsmr-2017-0006.

29. Sputnik (2016), Новые российские монеты возмутили дипломатов Литвы, 3.08.2016, Sputnik.lt, https://ru.sputniknews.lt/society/20160803/832298.html [dostęp: 17.04.2018].

30. Thussu D.K. (2007), News as entertainment: The rise of global infotainment, Londyn.

31. State Security Department of the Republic of Lithuania, (2018), National Threat Assessment.

32. Wilno, https://www.vsd.lt/wp-content/uploads/2018/03/ENG.pdf [dostęp: 17.04.2018].

33. Wolny-Zmorzyński K., Kaliszewski A., Furman W. (2006), Gatunki dziennikarskie, Warszawa.

34. Zimmer O. (2003), Boundary mechanisms and symbolic resources: towards a process-oriented approach to national identity, "Nations and Nationalism", vol. 9, nr 2, s. 173-193. DOI: https:// doi.org/10.1111/1469-8219.00081. 